\title{
Problems In Managing Waqf Endowment Asset In Bogor Regency
}

\author{
Ani Yumarni ${ }^{1}$, Endeh Suhartini ${ }^{2}$, Anna Sardiana ${ }^{3}$
}

\begin{abstract}
Problems In Managing Waqf Endowment Asset In Bogor Regency. Problems in Managing Waqf (Endowment) Assets in Bogor Regency. This article examines the problematics of empowering waqf objects in Bogor Regency. The aim is to increase the productivity of waqf property so that it can provide maximum benefits to the general public (ummah) in a sustainable manner. With such a large number of assets, if managed professionally, the waqf is believed to be able to become a pillar of the people's economy, especially in alleviating the problem of poverty in Bogor Regency. This study found the fact that among some key problems that could hinder the development of the waqf function in Bogor Regency was the less optimal role and function of Nazhir in developing waqf assets productively. Therefore, the involvement of the Indonesian Waqf Board (BWI) is urgently needed to improve Nazhir's competence in managing waqf assets in more productive ways.
\end{abstract}

Keywords: Waqf in Bogor Regency, nazhir role and function

Abstrak: Problematika Pengelolaan Aset Waqf di Kabupaten Bogor. Artikel ini menelaah tentang problematika pemberdayaan objek wakaf di Wilayah Hukum Kabupaten Bogor. Tujuannya adalah untuk meningkatkan produktivitas harta wakaf agar dapat memberi manfaat dan maslahat sebesar-besarnya kepada masyarakat umum (ummah) secara berkelanjutan Berdasarkan data yang diperoleh, di kabupaten Bogor terdapat aset wakaf berupa tanah sebanyak 5.686 lokasi dengan luas tanah 4.433.860 $\mathrm{M}^{2}$. Dengan jumlah aset wakaf yang sedemikian banyak, jika dikelola secara profesional, dapat dipastikan bahwa wakaf akan mampu menjadi sokoguru perekonomian umat, khususnya dalam mengentaskan masalah kemiskinan di Kabupaten Bogor. Penelitian ini memperoleh fakta bahwa di antara sejumlah masalah pokok yang dapat menghambat pengembangan fungsi wakaf di Kabupaten Bogor adalah kurang optimalnya peran dan fungsi Nazhir dalam mengembangkan aset wakaf secara produktif. Oleh sebab itu keterlibatan Badan Wakaf Indonesia (BWI) sangat dibutuhkan untuk meningkatkan kompetensi Nazhir dalam mengelola aset waqf secara lebih produktif.

Kata Kunci: wakaf di Kabupaten Bogor, peran dan fungsi Nazhir

\footnotetext{
${ }^{1,2}$ Universitas Djuanda Bogor, Jl. Tol Ciawi No. 1 Kotak Pos 35 Ciawi Bogor, Jawa Barat

${ }^{3}$ Postgraduate of Business School, University of Kuala Lumpur

E-mail: ${ }^{1}$ ani.yumarni@unida.ac.id, ${ }^{2}$ endeh.suhartini@unida.ac.id, ${ }^{3}$ anna.sardiana@s.unikl.edu.my
} 


\section{Introduction}

Socio-economic justice and equitable distribution of wealth and income are an inseparable part of Islamic moral philosophy. Both are essentially profiles of one face. Socio-economic justice cannot be realized without the distribution of income and wealth. For this reason, Islam emphasizes the principle of justice and brotherhood, the realization of which generates a spiritual commitment of the Muslim community to create a prosperous society under the auspices of the spirit of unity, humanity, and brotherhood. ${ }^{1}$

According to Adiwarman A. Karim, there are three pillars of the Islamic economy. First is the recognition of multi ownership. Islam recognizes the existence of private ownership, joint ownership (syirkah), and state ownership. This is very different from the classical capitalist concept which only recognizes private ownership or the classic social concept of shared ownership by communal or by the state. Second is freedom of economics as long as it does not violate the sharia guidelines or in the principles of fiqh al-ashlu fì al-muamalah al-ibähah (the basic principle of human economic relationship is permissible). Economics is a human activity that always develops dynamically. Therefore, new thinking is always needed to solve economic problems. Referring to the time of the Prophet and his companions would be very useful, but ijtihäd (law finding) in the economic field is certainly needed. the Messenger of Allah says, "You know better the affairs of your world," concerning the technique of pollinating plants. The Third is social justice. This is different from the concept of charity or donations in conventional economics. In the concept of Islamic economics, even the haläl sustenance earned with that effort is believed to have the rights of others. So, not because of the kindness of donating, but it is someone else's right. In Islam, it is not possible to carry out economic activities without involving others. ${ }^{2}$

${ }^{1}$ M. Umer Chapra, Towards a Just Monetary System, translate. Ikhwan Abidin Basri, (Jakarta: Gema Insani, 2000), p. 4.

2 Adiwarman A. Karim, Ekonomi Islam: Suatu Kajian Kontemporer (Jakarta: Gema Insani, 2018), p. 177. 
The Waqf order is part of the order to do good in the form of giving away of property whose benefits are not only limited to Muslims but also all humans without distinguishing their religion and beliefs. The legal basis of waqf refers to a history of Umar bin Khattab who had his land in Khaibar dedicated. In a hadith narrated from Ibn Umar ra, Umar ra. Was told to obtain a plot of land in Khaibar. Then he went to the Messenger of Allah, asking for suggestions. He said: "O Messenger of Allah (PBUH), I got a piece of land in Khaibar, I have not got such a good treasure, so what would you order me?" Rasulullah SAW. said: "If you like, you could hold the land, and give its benefits". Then Umar dedicated the land to be managed, not sold, not granted, and not bequeathed. Ibn Umar said: "Umar gave it (the benefits of the land) to the needy people, relatives, slaves, sabilillah (religious needs), ibn sabill, and guests. It is not prohibited for Nazhir to earn from the results in a good manner (as appropriate) or feed others without intending to accumulate wealth". (HR Bukhari, 2565: Muslim HR, 3085).

The Story of 'Umar is known to be very popular in the study of waqf that Ibn Hajar called it aslun (the origin/basis) for the prescription of waqf. Based on this hadith, Ibn Hajar claimed that 'Umar's waqf was the first waqf in Islamic history. In addition, he also made some conclusions about waqf that can be drawn from the hadith, including the presenting waqf in the form of land and rejecting opinions saying that waqf is not eternal or may be withdrawn by waqif (the waqf doer). Imam Al-Shafi' $i$ asserted that endowment is characteristic of Muslims and it is not known whether endowments ever occurred in jāhiliyah era (the time of ignorance). ${ }^{3}$

History shows that waqf is proven to be able to play an effective role in building the economy of the people while at the same time becoming an instrument of social security for community development and empowerment. The scope of the contribution of waqf in the development of society in the past was so wide and large, not only in

${ }^{3}$ Nurodin Usman, 'Studi Hadis-Hadis Waqf dalam Kitab Sahih Al-Bukhari dan Fath Al-Bari', Cakrawala: Jurnal Studi Islam, 10.2 (2015), 175-93. 
the social field but also in the economy, politics, education, and defense. ${ }^{4}$ This is because, empirically, the form of waqf can be divided into two: general waqf, which is useful for all people (including non-Muslims) such as waqf land for roads; and specific waqf, which are specific only to Muslims, such as endowments for mosques, Muslim cemetery, educational institutions, etc. ${ }^{5}$ Rasulullah SAW said: "If the child of Adam (human) dies, his deeds will be terminated, except for three cases; sadaqah jāriyah (charity), useful knowledge and pious children who pray for their parents "(HR. Muslim: 1631).

Meanwhile, a large number of Muslims in Indonesia, even the largest in the world, is an important asset that can be utilized for the collection and development of waqf. Based on the assumption of Cholil Nafis, as quoted by M. Nur Rianto Al Arif, if 1 million Muslims donate their funds in the amount of Rp 100,000 per month, waqf funds will be collected in the amount of $\mathrm{Rp} 100$ billion/month or Rp 1.2 trillion per year. If 20 million Indonesian Muslims collect endowments in the amount of Rp 100 thousand every month, the funds collected will reach the amount of Rp 24 Trillion/year. Likewise, if 50 million people are represented, each year a waqf fund of $\mathrm{Rp} 60$ trillion will be collected. ${ }^{6}$

The big potential of waqf, as long as it is managed professionally and productively, will become such a great force that can be utilised to support the benefit and welfare of the people. ${ }^{7}$ Because of the large benefits arising from waqf, as Masykuri Abdillah asserted, the matter of organizing waqf is not enough to be understood only in terms of the law, but can also be understood from the standpoint of philosophy and wisdom, namely as (1) Social Worship, (2) means of channeling endless rewards, (3) endowments for worship facilities and infrastructure and

${ }^{4}$ Mardani, Hukum Islam: Zakat, Infak, Sedekah dan Waqf (Bandung: Citra Aditya Bakri, 2016), p. 173.

5 Jaih Mubarok, 'Waqf dan Pendidikan Islam,"', Jurnal Waqf dan Ekonomi Islam, 6.1 (2013) accessed from <https://drive.google.com/file/d/0B61irU-NYtRTSU1Da09IUHhSVXM/view>.

${ }^{6}$ Mardani, Hukum Islam: Zakat, Infak, Sedekah dan Waqf.

${ }^{7}$ Mustofa Edwin Nasution dan Uswatun. Hasanah, 'Waqf Tunai Inovasi Finansial Islam (Peluang dan Tantangan dalam Mewujudkan Kesejahteraan Umat)' (Study Program of Islam and Middle East : University of Indonesia, 2006). 
social activities, (4) endowments for improving human civilization, and (5) endowments for improving the public welfare. ${ }^{8}$

At present, the potential and utilization of zakat funds, both managed by the National Amil Zakat Agency (BAZNAS), the Amil Zakat Institution (LAZ), and other Ziswaf institutions, have received recognition from National Development Planning Authorities (BAPPENAS). This is reflected in the data of the Ministry of PPN/Bappenas appear in the Indonesian Sharia Finance Architecture which assumes 70 percent or Rp 509.6 trillion of sharia financial resources in Indonesia come from zakat funds and endowments. The concrete potential, based on BAZNAS research (2011), for Zakat is Rp 217 trillion, while the potential for endowments in particular money or cash endowments is Rp 377 trillion per year.' Concerning the potential of waqf in the form of land, data presented by the Indonesian Waqf Board (BWI) shows the number of waqf land in Indonesia recorded as many as 435,768 locations with a land area of $4,359,443,170 \mathrm{~m} 2 .{ }^{10}$

Undeniably, the great potential of Zakat and Waqf requires good management and utilization of its managers (Nazhir). As one of the elements that must exist in the implementation of waqf, the existence of Nazhir is one of the uniqueness of the form of management of Islamic philanthropic funds. Nazhir's role is to manage and empower waqf objects so that the existence of waqf can provide maximum and sustainable benefits for the general public (ummah).

This research was conducted to examine the problems of waqf in the Bogor Regency. The ultimate goal is to encourage the realization of professionalism and productivity in the development of waqf property as desired by Law Number 41 of 2004 concerning Waqf.

${ }^{8}$ Masykuri Abdillah, 'Filosofi dan Hikmah Waqf' <https://bwi.or.id/index.php/publikasi/ artikel/356-filosofi-dan-hikmah-waqf.html,> [accessed 12 November 2019].

${ }^{9}$ M. Fuad Nasar, 'Zakat dan Waqf Membangun Infrastruktur Sosial', Bimasislam.Kemenag. Go.Id accessed from <https://bimasislam.kemenag.go.id/post/opini/zakat-dan-waqf-membanguninfrastruktur-sosial-> [accessed 15 October 2019].

10 'Data Waqf - Badan Waqf Indonesia' <https://www.data.bwi.go.id/> [accessed on 16 October 2019]. 


\section{Provisions of Waqf in Indonesia}

Waqf, according to Article 1 of Law Number 41 the Year 2004, is a legal act of wāqif (the party that donates his property) to separate and/or give away a portion of his property to be used forever or for a certain period following his interests for worship and/or general welfare according to sharia. ${ }^{11}$

To be declared valid, the waqf (endowments) must be carried out according to Sharia provisions. The pledge of waqf was carried out by the wakif to nadzir in the presence of PPAIW witnessed by 2 (two) witnesses. The pledge of Waqf, as referred to, is stated verbally and/ or in writing and stated in the deed of endowment pledge by PPAIW. In the case of wāqif unable to declare the endowment pledge verbally or to attend the implementation of the endowment pledge for reasons justified by law, the wäqif can appoint his representative with a letter of designation and affirm by 2 (two) witnesses. ${ }^{12}$ Endowments that have been pledged cannot be canceled. ${ }^{13}$

The pledge of the endowment is outlined in the deed of endowment pledge, at least includes a. the name and identity of the Wâkif; b. Nazhir's name and identity; c. data and description of waqf property; d. allotment of waqf property; e. endowment period. Further provisions regarding the endowment pledge deed as referred to in paragraphs are regulated by Government Regulation. ${ }^{14}$

The manager of a waqf in Islam is termed as Nazhir. In Government Regulation Number 28 of 1977 concerning Land Ownership Representation, the word Nazhir is defined as an individual or a group of people or legal entities entrusted with the task of maintaining and managing endowments. ${ }^{15}$

${ }^{11}$ Waqf Act No. 41 of 2004 Article 1 Paragraph (1).

${ }_{12}$ Waqf Act no. 41 of 2004 Article 17,18

${ }^{13}$ Waqf Act no. 41 of 2004 Article 2, 3.

${ }^{14}$ Waqf Act no. 41 of 2004 Article 22

15 'This Definition Was Adopted by the Compilation of Islamic Law (KHI) as Stated in Article 215 Paragraph'. 
According to Article 9, and 10 paragraphs (1), (2) and (3) of Law Number 41 of 2004, Nazhir (endowment manager) can be in the form of (1) Individuals, (2) Organizations, and or (3) Legal Entities. If Nazhir is an individual he must meet the following requirements: (1) Indonesian citizens, (2) Muslim, (3) mature, (4) trustworthy, (5) physically and spiritually capable, and (6) not hindered from doing legal actions. If the Nazhir is an organization, the requirements that must be met include: (1) the management of the relevant organization meets the Nazhir individual requirements, and (2) the organization is engaged in the social, educational, or religious fields of Islam. Whereas if it is a Legal Entity, the requirements are (1) the management of the legal entity concerned fulfills the individual Nazhir requirements, (2) the legal entity is formed following the applicable laws and regulations, and (3) the legal entity concerned is engaged in social affairs, Islamic education, society and/or religion.

Nazhir was obliged to manage and develop waqf property following its purpose, function, and designation. The management and development of waqf property by Nazhir are carried out following the sharia principles and productively. In the case of the management and development of the endowments required a guarantor, an Islamic guarantor institution shall be used. Nazhir is prohibited from making changes to the designation of waqf property except based on written permission from the Indonesian Waqf Board (BWI). The permit can only be granted if the endowment property turns out to unusable following the allotment stated in the endowment pledge. Nazhir's duties and responsibilities include: (a). Administering waqf property; (b). Managing and developing waqf property following its purpose, function, and designation; (c). Supervising and protecting endowments property; (d). Reporting the implementation of his duties to the Indonesian Waqf Board. ${ }^{16}$ In carrying out his duties, Nazhir may receive a reward from the net proceeds of the management and development of waqf property which amount does not exceed $10 \%$ (ten percent). ${ }^{17}$

\footnotetext{
16 Waqf Act no. 41 of 2004 Article 11,
}

17 Waqf Act no. 41 of 2004 Article 12. 
Furthermore, to make the management of waqf property run as expected, Nazhir obtained guidance from the Minister and the Indonesian Waqf Board. ${ }^{18}$ Apart from that, Nazhir was also supervised by a supervisory agency, which according to Article 56 of Government Regulation No. 42/2006 concerning the Implementation of Law No. 41/2004 concerning Waqf, was carried out by the government and the community, both actively and passively. Active supervision is carried out through direct examination of Nazhir's performance in waqf management, at least once a year; Whereas passive supervision is carried out by observing various reports submitted by Nazhir relating to the management of waqf. ${ }^{19}$

Nadzir resigns from his post and is replaced by another Nazhir if : (1) He dies (Nazhir individual); (2) was disbanded or dissolved following the provisions of the applicable laws and regulations (for Nazhir organizations or Nazhir legal entities); (3) at his request; (4) do not carry out their duties as Nazhir and/or violate the prohibition in the management and development of waqf property of the applicable laws and regulations; (5) convicted by a court that has permanent legal force. Dismissal and replacement of Nazhir are carried out by the Indonesian Waqf Board. ${ }^{20}$

If a dispute arises about waqf, then a settlement is taken through deliberation to reach consensus. If it is unsuccessful, the dispute can be resolved through mediation, arbitration, or in the Religious Court. ${ }^{21}$ However, if the dispute concerns ownership rights, then the settlement is no longer examined in the Religious Courts, but rather becomes the authority of the General Courts. This is as regulated in Article 50 of Law Number 7/1989 concerning Religious Courts (as amended by Law Number 3 of 2006 in conjunction with Law Number 50 of 2009) which provides provisions that in matters relating to property and civil rights, it becomes the authority of the General Court and not the authority of the Religious Court. ${ }^{22}$ The granting of authority to the General Court may

\footnotetext{
${ }^{18}$ Waqf Act no. 41 of 2004 Article 13

${ }^{19}$ Waqf Act no. 41 of 2004 Article 12

20 Waqf Act no. 41 of 2004 Article 45

${ }^{21}$ Waqf Act no. 41 of 2004 Article 62

${ }^{22}$ Sutedi, Peralihan Hak Atas Tanah dan Pendaftarannya (Jakarta: Sinar Grafika, 2006), p. 1.
} 
be based on consideration/agreement among legal experts that the waqf institution arises as customary law of the Indonesian people. Therefore, even though this waqf institution is essentially derived from Islamic law, but in reality, it is considered as if it has entered the realm of Indonesian traditional law.

\section{Some Problems around Waqf in the Bogor Regency Area}

M. Fuad Nasar identifies six actual issues relating to the management of waqf property that needs attention and solutions from the government and the community. First, the lack of dynamic data accuracy of waqf assets, including cash waqf (cash waqf). Second, the low number of money waqf collection. Third, there is still a lot of waqf land that has not been certified and not been used optimally for the benefit of the people. Fourth, there are still many waqf land seized by property companies, taken back by the heirs, lost, or used illegally, including ruislag (swapping). Fifth, the lack of utilization of waqf assets for productive economic activities and the added value to the welfare of the people. Sixth, the capacity and sense of responsibility of Nazhir (waqf managers) which still need to be improved. ${ }^{23}$

Of the six main problems above, if related to existing conditions in the Bogor Regency, three problems need to be prioritized to be resolved namely: (1) Problems with the status/legality of waqf land; (2) Role of Nazhir and Competencies; (3) Problems in developing waqf productivity

\section{A. Problems with the legal status of waqf land}

Based on data obtained from the Bogor Regency Ministry of Religion Office, the total number of waqf assets in the form of land in the Bogor Regency area was 4,433,860 m2 spread over 5,686 locations. the details are as follows:

${ }^{23}$ M. Fuad Nasar, 'Zakat dan Waqf Membangun Infrastruktur Sosial’ Bimasislam. Kemenag. go.id <https://bimasislam.kemenag.go.id/post/opini/zakat-dan-waqf-membangun-infrastruktursosial->. 
Table 1. Number of Waqf Assets in the Form of Land in Bogor Regency ${ }^{24}$

\begin{tabular}{|c|c|c|c|c|c|c|c|c|c|}
\hline \multirow{3}{*}{ No } & \multirow{3}{*}{$\begin{array}{c}\text { KUA } \\
\text { District }\end{array}$} & \multicolumn{8}{|c|}{ WAQF LAND STATUS } \\
\hline & & \multicolumn{2}{|c|}{ AIW } & \multicolumn{2}{|c|}{$\begin{array}{c}\text { BEING } \\
\text { PROCESSED } \\
\text { IN BPN }\end{array}$} & \multicolumn{2}{|c|}{ CERTIFIED } & \multicolumn{2}{|c|}{ TO T A L } \\
\hline & & $\begin{array}{l}\text { Loca } \\
\text { tion }\end{array}$ & $\begin{array}{l}\text { Area } \\
\text { (m2) }\end{array}$ & $\begin{array}{l}\text { Loca } \\
\text { tion }\end{array}$ & $\begin{array}{l}\text { Area } \\
(\mathrm{m} 2)\end{array}$ & $\begin{array}{l}\text { Loca } \\
\text { tion }\end{array}$ & $\begin{array}{l}\text { Area } \\
(\mathrm{m} 2)\end{array}$ & $\begin{array}{l}\text { Loca } \\
\text { tion }\end{array}$ & $\begin{array}{l}\text { Area } \\
(\mathrm{m} 2)\end{array}$ \\
\hline 1. & Nanggung & 6 & 14.988 & 0 & 0 & 170 & 68.680 & 176 & 83.668 \\
\hline 2. & Leuwiliang & 0 & 0 & 0 & 0 & 0 & 0 & 0 & 0 \\
\hline 3. & Leuwisadeng & 12 & 26.187 & 2 & 1.812 & 98 & 86.522 & 112 & 114.521 \\
\hline 4. & Pamijahan & 9 & 29.334 & 0 & 0 & 212 & 204.271 & 221 & 233.605 \\
\hline 5. & Cibungbulang & 16 & 14.627 & 0 & 0 & 221 & 118.120 & 237 & 132.747 \\
\hline 6. & Ciampea & 9 & 10.691 & 0 & 0 & 137 & 87.313 & 146 & 98.004 \\
\hline 7. & Tenjolaya & 17 & 8.995 & 0 & 0 & 40 & 33.578 & 57 & 42.573 \\
\hline 8. & Dramaga & 11 & 5.620 & 1 & 200 & 76 & 33.448 & 88 & 39.268 \\
\hline 9. & Ciomas & 10 & 7.160 & 8 & 2.584 & 107 & 52.782 & 125 & 62.526 \\
\hline 10. & Tamansari & 5 & 21.665 & 0 & 0 & 35 & 12.640 & 40 & 34.305 \\
\hline 11. & Cijeruk & 24 & 23.396 & 1 & 1.608 & 144 & 49.189 & 169 & 74.193 \\
\hline 12. & Cigombong & 17 & 37.615 & 0 & 0 & 128 & 84.190 & 145 & 121.805 \\
\hline 13. & Caringin & 16 & 23.743 & 0 & 0 & 131 & 79.119 & 147 & 102.862 \\
\hline 14. & Ciawi & 8 & 2.145 & 0 & 0 & 82 & 81.241 & 90 & 83.386 \\
\hline 15. & Cisarua & 2 & 2.605 & 0 & 0 & 116 & 110.618 & 118 & 113.223 \\
\hline 16. & Megamendung & 5 & 1.937 & 0 & 0 & 81 & 72.360 & 86 & 74.297 \\
\hline 17. & Sukaraja & 27 & 14.603 & 7 & 1.002 & 131 & 71.072 & 165 & 86.677 \\
\hline 18. & Babakan Madang & 22 & 18.254 & 2 & 1.332 & 101 & 58.798 & 125 & 78.384 \\
\hline 19. & Suka makmur & & 2 & 3.372 & 0 & 0 & 78 & 25.070 & 828.442 \\
\hline 20. & Cariu & 6 & 8.432 & 3 & 881 & 92 & 56.449 & 101 & 65.762 \\
\hline 21. & Tanjungsari & 0 & 0 & 4 & 4.114 & 97 & 34.596 & 101 & 38.710 \\
\hline 22. & Jonggol & 22 & 61.829 & 0 & 0 & 159 & 90.979 & 181 & 152.808 \\
\hline 23. & Cileungsi & 68 & 53.866 & 2 & 600 & 166 & 67.587 & 236 & 122.053 \\
\hline 24. & Klapanunggal & 9 & 21.194 & 6 & 3.397 & 53 & 23.212 & 68 & 47.803 \\
\hline 25. & Gunungputri & 7 & 20.969 & 0 & 0 & 197 & 92.529 & 204 & 113.498 \\
\hline 26. & Citeureup & 29 & 12.340 & 0 & 0 & 158 & 67.433 & 187 & 79.773 \\
\hline 27. & Cibinong & 15 & 28.819 & 7 & 1.266 & 196 & 150.476 & 218 & 180.561 \\
\hline 28. & Bojonggede & 39 & 21.035 & 0 & 0 & 153 & 104.104 & 196 & 125.139 \\
\hline 29. & Tajurhalang & 11 & 13.149 & 0 & 0 & 78 & 85.537 & 89 & 98.686 \\
\hline 30. & Kemang & 29 & 34.073 & 4 & 6.573 & 81 & 64.184 & 114 & 104.830 \\
\hline
\end{tabular}

24 'The Data Were Obtained from the Office of the Ministry of Religion of Bogor Regency, on 12 July 2019'. 


\begin{tabular}{|c|c|c|c|c|c|c|c|c|c|}
\hline \multirow{3}{*}{ No } & \multirow{3}{*}{$\begin{array}{c}\text { KUA } \\
\text { District }\end{array}$} & \multicolumn{8}{|c|}{ WAQF LAND STATUS } \\
\hline & & \multicolumn{2}{|c|}{ AIW } & \multicolumn{2}{|c|}{$\begin{array}{c}\text { BEING } \\
\text { PROCESSED } \\
\text { IN BPN }\end{array}$} & \multicolumn{2}{|c|}{ CERTIFIED } & \multicolumn{2}{|c|}{ TO T A L } \\
\hline & & $\begin{array}{l}\text { Loca } \\
\text { tion }\end{array}$ & $\begin{array}{l}\text { Area } \\
(\mathrm{m} 2)\end{array}$ & $\begin{array}{l}\text { Loca } \\
\text { tion }\end{array}$ & $\begin{array}{l}\text { Area } \\
(\mathrm{m} 2)\end{array}$ & $\begin{array}{l}\text { Loca } \\
\text { tion }\end{array}$ & $\begin{array}{l}\text { Area } \\
(\mathrm{m} 2)\end{array}$ & $\begin{array}{l}\text { Loca } \\
\text { tion }\end{array}$ & $\begin{array}{l}\text { Area } \\
(\mathrm{m} 2)\end{array}$ \\
\hline 31. & Rancabungur & 4 & 2.775 & 0 & 0 & 47 & 40.430 & 51 & 43.205 \\
\hline 32. & Parung & 19 & 15.719 & 0 & 0 & 202 & 205.629 & 221 & 221.348 \\
\hline 33 & Ciseeng & 0 & 0 & 4 & 29.433 & 153 & 157.133 & 157 & 186.566 \\
\hline 34. & Gunung sindur & 24 & 18.160 & 0 & 0 & 110 & 110.991 & 134 & 129.151 \\
\hline 35. & Rumpin & 10 & 24.145 & 0 & 0 & 208 & 207.244 & 218 & 231.389 \\
\hline 36. & Cigudeg & 2 & 1.251 & 0 & 0 & 174 & 348.326 & 176 & 349.577 \\
\hline 37. & Sukajaya & 1 & 204 & 1 & 500 & 71 & 17.059 & 73 & 17.763 \\
\hline 38. & Jasinga & 0 & 0 & 2 & 1.568 & 191 & 200.571 & 193 & 202.139 \\
\hline 39. & Tenjo & 17 & 8.995 & 0 & 0 & 40 & 33.578 & 57 & 42.573 \\
\hline 40. & Parung panjang & 18 & 42.605 & 5 & 4.460 & 102 & 52.320 & 125 & 99.385 \\
\hline & Total Assets & 550 & 658.456 & 61 & 627.110 & 5.075 & 3.712 .514 & 5.686 & 4.433 .860 \\
\hline
\end{tabular}

Most (70.07\%) of the assets mentioned above are intended for houses of worship and taklim assemblies, with details: mosque 2,139 locations (37.61\%); Musholla 1,478 locations (25.99\%); taklim assembly 368 locations (6.47\%). pesantren/madrasah 367 locations $(6.45 \%)$, while the rest are intended for social purposes in the form of: Public cemeteries 248 locations (4.86\%); school 146 locations (2.56\%), government institutions 24 locations $(0.42 \%)$, agriculture 8 locations $(0.14 \%)$; social 3 locations $(0.05 \%)$, and others 101 locations $(1.77 \%){ }^{25}$

Of the 5,686 waqf land locations in Bogor Regency, as many as 5,075 locations (89.23\%) already have certificates, 61 locations $(1.07 \%)$ are still in the process in BPN, 550 locations (9.67\%) only have AIW. ${ }^{26}$ These uncertified waqfs, even though they are few in number, are prone to cause conflicts. Because not a few lands that have been claimed as a waqf, in the end, become the object of the dispute. Waqf land that has been going on for decades ago, and the wakif has passed away, is being sued again by the heirs or other parties who deny the existence of legal

25 'Document the Office of the Ministry of Religion, Bogor Regency.'

26 'Document the Office of the Ministry of Religion, Bogor Regency.' 
representation by submitting proof of ownership of the land. Indeed, before the enactment of Law Number 41 of 2004 concerning Waqf, the practice of waqf that occurred in community life was still conventional in nature. Wakiflandowner with full trust and ta'dzîm (respect), just, verbally, give away his land to community leaders or people who are considered credible and able to manage waqf without the support of written documents. This kind of practice can later lead to conflicts between the community and certain parties as a result of not fulfilling the legal requirements of the transfer of land rights, from the status of ownership to the waqf land.

To overcome this problem, the Minister of Religion and the Minister of Agrarian Affairs and Spatial Planning/National Land Agency have made a Memorandum of Understanding outlined in a Joint Agreement Letter Number 9 of 2015 and Number 9/SKB/V/2015 dated May 25, 2015, concerning the Acceleration of Endowment Land Certification. With the existence of this MOU, the acceleration of the waqf land legalization process has become possible and inexpensive through the Complete Systematic Land Registration (PTSL) Ministry of ATR/BPN. ${ }^{27}$

\section{B. Problems with waqf productivity development}

By looking at the area and the number of waqf assets in the Bogor Regency, it can be assumed that the potential of waqf in supporting the economic life of the people of this region is quite large. Unfortunately, such a large asset has not been managed professionally to support the economy of the people, especially in alleviating the problem of poverty in Bogor Regency. Many endowments are in a stagnant condition and have not been managed optimally. If the endowment is intended for some purposes, for example, a place of worship or educational facilities, then from year to year the function of waqf is solely for houses of worship or places of education. There is no effort to make other developments so that endowments can have added value. As a result, waqf assets become

27 'Kemenag Dorong Percepatan Sertifikasi Tanah Waqf — Nusakini' <https://nusakini. $\mathrm{com} /$ news/kemenag- dorong-percepatan-sertifikasi-tanah-waqf> [accessed 9 November 2019]. 
less productive and provide less economic benefits for the surrounding community. Indeed, in the public, there is still a belief that waqf assets should not be developed outside of the intended designation of waqif. So if the waqif gives its land for the building of a place of worship, then in that location it is enough to build a mosque or a prayer place, no other use may be made outside of its original designation.

The public perspective claiming that waqf assets should not be developed outside of their original designation needs to be reviewed and rectified. Herein lies the importance of the role and involvement of religious leaders to enlighten the community, as well as professionalism and productive thinking of a Nazhir so that waqf assets can contribute to ensuring the sustainability of the social interests of the community. The vast and untapped land can be strived to bring added value economically and sustainably or other interests needed by the community. For example the use of land for agricultural land, fish ponds, tourist areas, palawija plantations, home industry businesses, or other allotments that can bring value economically, in addition to the original allotment intended by the endowment.

An example of a model for developing waqf assets productively can be seen from what has been carried out by the waqf management agency Yayasan Al-Falah Social Fund (YDSF) in Surabaya. As reported by Miftahul Huda, YDSF, in developing waqf assets, has used waqf fundraising management by developing the resource fundraising model, in the form of raising conventional sources both directly and indirectly, and the grant fundraising model, in the form of strengthening empowerment programs in waqf distribution. This method was adopted because YSDF has not been able to develop an asset fundraising model and in-kind endowments.

Another example of a waqf management and development model can also be seen from what YBSA and YBW UII have done. Although basically, the two foundations have the same institutional model, in the form of a foundation/Nazhir legal entity, the two institutions have different concepts, both philosophical and technical development, and management. YBSA does not separate endowment property from assets obtained from the results of the endowment property development, both are made as endowments that are mandated to be managed responsibly. While YBW 
UII separates waqf property from development assets, which are then used to manage the education institution independently based on the capital of waqf property. Apart from differences in the concept of implementation, the two models of management and development of waqf above are economic ijtihad and are proven capable of making waqf assets more efficient for the people and the advancement of education in Indonesia. ${ }^{28}$

The examples above should be emulated by all waqf managers throughout the country. The nature and definition of waqf more loosely formulated by law show that waqf must produce and provide continuous benefits. Therefore, the need for independent and sustainable organizational management functions is an initial requirement that cannot be neglected. The pattern of waqf land management that still applies the conventional management needs to be changed to apply a modern management pattern that is more innovative and has more added value. For this reason, the Ministry of Religion of the Republic of Indonesia encourages waqf managers to establish business partnerships with other parties (business people or investors) to take advantage of strategic land positions and have high commercial value. The intended third parties include:

1) Business Investment Institutions in the form of non-financial service business institutions;

2) Individual investments that have sufficient capital;

3) Islamic banking institutions or other Islamic financial institutions as the owner of the loan funds;

4) International banking institutions concerned with the development of waqf land in Indonesia;

5) Financial institutions with a BOT (Build of Transfer) system;

6) Sharia guarantor institution as the party that will become Nazhir if the endowment empowerment effort suffers losses;

7) Non-Governmental Organizations (NGOs) that care about the economic empowerment of the people. ${ }^{29}$

${ }^{28}$ Amir Mu'allim, 'Ijtihad Ekonomi dalam Pengelolaan Aset Waqf', $A L$-'ADALAH, 14.2 (2017), 291-310 <https://doi.org/10.24042/adalah.v14i2.2212>.

${ }^{29}$ Departemen Agama RI, 'Paradigma Baru Waqf di Indonesia', (Direktorat Jenderal 
With the waqf development model that is managed professionally by Nazhir who is trusted under the guidance of the BWI Institute, waqf assets will be able to bring more useful results and support the benefit of the people, both in the form of developing mosque/musholla facilities, Islamic educational institutions, Islamic hospital development, or for the benefit of other people's economic empowerment assistance, which is not contrary to sharia and laws and regulations.

\section{Problems with the Role and Nazhir' competency}

The non-optimal development of the waqf land productivity above actually correlates with the low competency of waqf managers or Nazhir. ${ }^{30}$ This study obtained the fact that among the main problems that could hinder the development of waqf function in Bogor Regency was the less optimal role and function of Nazhir in developing waqf assets productively. Many endowments do not develop as they should, because Nazhirs are reluctant to take the initiative, worrying that development will go against the wäkif's intention when he gave his assets to be used as endowments. Apart from that, most Nazhirs, especially those in the form of individuals, do not familiar with modern management, especially in making financial reports, so that sometimes the public, or related parties, find it difficult to measure the extent of effectiveness of waqf asset development, including the results.

As stated earlier, the role of Nazhir in developing the potential of waqf is very important, if it cannot be said to be a major factor in ensuring the sustainability and empowerment of productive waqf assets. Therefore, in the future, in the appointment of Nazhir, the community must seriously consider the capabilities and competence of a Nazhir in the aspects of management and development of waqf objects. Related to that need, the parameters of professional Nazhir formulated by Achmad

\footnotetext{
Bimbingan Masyarakat Islam, Direktorat Pemberdayaan Waqf, 2003), p. 126.

${ }^{30}$ Nurul Huda, et al, "Prioritas Solusi Permasalahan Waqaf di Provinsi Jawa Barat dengan Metode ANP"', Al-Awqaf; Jurnal Waqf Dan Ekonomi Islam, 8.1 (2015) <https://drive.google. com/file/d/0B61irU-NYtRTZWJhV3ZPWThEbGs/view>.
} 
Junaidi, quoted by Jaih Mubarok, ${ }^{31}$ need to be used as guidelines, which include: amanah (trustworthy), Shidī (honest), fathänah (intelligent), and tabligh (transparent). The character of trustworthy Nazhir resources are: (1) educated and high in morality, (2) having superior and competitive skills, (3) ability to divide labor, (4) ability to carry out obligations and obtain fair rights, and (5) having clear and directed operational work standards.

Apart from that, there is also a need for continuous coaching efforts from the Indonesian Waqf Board (BWI), in the form of (1) regular meetings (2) training activities, and (3) socialization related to the latest regulations on the management of waqf objects. Up to now, the working relationship between the Ministry of Religion of Bogor Regency, KUA as PPAIW, the Indonesian Waqf Agency Representative of Bogor Regency, and Nazhir has been running even though it has not been optimal. Therefore, in the future, the above institutions need to be more intensive in carrying out the fostering functions, formally and informally, especially in the field of administration and supervision of waqf objects in the area of Bogor Regency.

\section{Conclusion}

The three main problems related to existing waqf conditions in the Bogor Regency are: (1) Problems with the status/legality of waqf land; (2) Role of Nazhir and Competencies; (3) Problems in managing and developing waqf productivity

To overcome such problems, stakeholders in the Bogor Regency, in this case, the Ministry of Religion, BWI Representatives of Bogor Regency, and Nazhir, need to build integrated coordination and supervision in one system (integrated system) related to the overall management, development, and supervision of waqf assets. This is important because even though the laws and regulations have provided legal certainty if it is not followed by the efforts and hard work of the stakeholders in implementing the purpose of the law, the waqf assets will never be able to develop into one of the instruments social Security.

\footnotetext{
${ }^{31}$ Jaih Mubarok, Waqf Produktif (Bandung: Simbiosa Rekatama Media, 2008), p. 161.
} 


\section{Bibliography}

A. Karim, Adiwarman, Ekonomi Islam: Suatu Kajian Kontemporer, Jakarta: Gema Insani, 2018.

Abdillah, Masykuri, 'Filosofi dan Hikmah Wakaf' <https://bwi.or.id/index. php/publikasi/artikel/356-filosofi-dan-hikmah-wakaf.html,> Chapra, M. Umer, Towards a Just Monetary System, Diterjemahkan Oleh Ikhwan Abidin Basri, Jakarta: Gema Insani, 2000.

Compilation of Islamic Law (KHI), Article 215 Paragraph'

'Data Wakaf - Badan Wakaf Indonesia' < https://www.data.bwi.go.id/>.

Departemen Agama RI, Paradigma Baru Wakaf di Indonesia' Direktorat Jenderal Bimbingan Masyarakat Islam, Direktorat Pemberdayaan Wakaf, 2003.

'Document the Office of the Ministry of Religion, Bogor Regency.'

'Kemenag Dorong Percepatan Sertifikasi Tanah Wakaf - Nusakini' $<$ https://nusakini.com/news/kemenag-dorong-percepatan-sertifikasitanah-wakaf>

Mubarok, Jaih, 'Wakaf dan Pendidikan Islam,", Jurnal Wakaf Dan Ekonomi Islam, 6.1 (2013), 6-20

—, Wakaf Produktif, Bandung: Simbiosa Rekatama Media, 2008.

Mardani, Hukum Islam: Zakat, Infak, Sedekah dan Wakaf, Bandung: Citra Aditya Bakri, 2016.

Mu'allim, Amir, 'Ijtihad Ekonomi dalam Pengelolaan Aset Wakaf', $A L$ 'ADALAH, 14.2 (2017), 291-310 <https://doi.org/10.24042/adalah. v14i2.2212>

Mustofa Edwin Nasution dan Uswatun. Hasanah, Wakaf Tunai Inovasi Finansial Islam (Peluang Dan Tantangan dalam Mewujudkan Kesejahteraan Umat), Program Studi Timur Tengah dan Islam: Universitas Indonesia, 2006.

Nasar, M. Fuad, 'Zakat dan Wakaf Membangun Infrastruktur Sosial', Bimasislam.Kemenag.go.id <https://bimasislam.kemenag.go.id/post/ opini/zakat-dan-wakaf-membangun-infrastruktur-sosial->

Nurul Huda, et al, "Prioritas Solusi Permasalahan Waqaf di Provinsi 
Jawa Barat Dengan Metode ANP"', Al-Awqaf; Jurnal Wakaf dan Ekonomi Islam, 8.1 (2015) <https://drive.google.com/file/d/0B61 irUNYtRTZWJhV3ZPWThEbGs/view>

Sutedi, Peralihan Hak Atas Tanah dan Pendaftarannya, Jakarta: Sinar Grafika, 2006.

Usman, Nurodin, 'Studi Hadis-Hadis Wakaf dalam Kitab Sahih AlBukhari dan Fath Al-Bari', Cakrawala: Jurnal Studi Islam, 10.2 (2015), 175-93.

Waqf Act No. 41 of 2004 